\title{
Proceeding
}

Supplementary Issue: Spring Conferences of Sports Science. First International Conference in Iraq on Sport for Peace, 4 April 2019. Baghdad Science Institute, Baghdad, Iraq.

\section{Modern approaches to the development of the sport education system in developed countries}

\author{
A. CHEMERILOVAI ${ }^{1}$, N. MYAGKOVAS², V. LITVINOVS² ${ }^{2}$ L. G. CHUVAKHINA², N. A. RABOTNIKOVA² \\ ${ }^{1}$ Chuvash State University, Russian Federation \\ ${ }^{2}$ Russian State University of Physical Education, Sport, Youth and Tourism, Russian Federation
}

\begin{abstract}
The problems of sport educational preparation are in the center of attention of the leadership of many countries. Educational training is considered as a factor of competitiveness in the labor market, taking into account the peculiarities of the modern economy. In the 21st century, the sources of economic growth are changing qualitatively. Intellectual production resources take priority. A person with fundamental educational and professional knowledge becomes the main factor in the economy. The principles of continuity of education, integration of general educational and vocational training are leading. Purposeful formation of a qualified employee begins in the upper grades of secondary schools, which is especially evident in the example of the United States. Today, in the face of growing competition in the global labor market, the main task is to ensure that pupils receive secondary education and are prepared for entry to colleges and universities. Education is financed by public and private funds. Increasing the availability of education for various categories of citizens allows developed countries to dominate in the world economy. Keywords: Sport educational process; Primary school; Secondary school; Higher education; Bachelor's degree; Vocational training; Education financing; Labour market.

\section{Cite this article as:}

Chemerilovai, A., Myagkovas, N., Litvinovs, V., Chuvakhina, L.G., \& Rabotnikova, N.A. (2019). Modern approaches to the development of the sport education system in developed countries. Journal of Human Sport and Exercise, 14(4proc), S497-S504. doi:https://doi.org/10.14198/jhse.2019.14.Proc4.08

Corresponding author. Cheboksary, Russian Federation, 429955, Ph. D. (Pedagogics), Associate Professor Philosophy, Sociology, Pedagogics, Chuvash State University named after I.N. Ulyanov.

E-mail: aleksandrovna.lg@mail.ru

Supplementary Issue: Spring Conferences of Sports Science. First International Conference in Iraq on Sport for Peace, 4 April 2019. Baghdad Science Institute, Baghdad, Iraq.

JOURNAL OF HUMAN SPORT \& EXERCISE ISSN 1988-5202

(c) Faculty of Education. University of Alicante

doi:10.14198/jhse.2019.14.Proc4.08
\end{abstract}




\section{INTRODUCTION AND IMPORTANCE OF RESEARCH}

At the beginning of the 21st century, problems related to the development of the education system, its accessibility and quality are becoming more pronounced.

Research in the field of education in different countries confirms the variety of forms, methods and terms of study provided by public and private educational institutions.

The educational factor is one of the key factors of employment, since the highest unemployment rates are found among people who have not completed school. Education is traditionally associated with the prospect of a higher income, the possibility of self-realization as a result of acquiring professional skills, determining a place on the labour market, and achieving career growth. The incomes of persons with higher education are on average 3 times or higher than the incomes of workers with primary or incomplete secondary education.

At the level of schooling in developed countries, the indicators approach $90 \%$ for all age groups of the population. At the level of higher education levels, the differences remain significant. For example, in the USA, among people of Asian descent, almost 54\% have a bachelor's degree, among African Americans, $23 \%$ have a bachelor's degree, and among Hispanic people, $16 \%$ have a bachelor's degree (Educational Attainment in the US. census Bureau, 2016).

In the US, there is no unified public education system. According to the US Constitution, the responsibility for organizing the educational process rests upon the state government.

An innovative approach to the development of education is the desire for the professional identification of students. Education in the United States is regarded as the main driver of employee success in the labour market and the stability of his employment.

\section{THEORETICAL ASPECTS OF THE STUDY}

A discussion of the main theoretical approaches to determining the role of educational institutions in preparing students for work One of the most serious issues in the development of the education system is the identification of priorities in the activities of educational institutions.

There are two main theoretical approaches outlined in the fundamental research of representatives of two scientific schools.

Representatives of the so-called progressive scientific school such as L. Kremin, J. Cousol, P. Graham, P. Bodien, J. Hoyt consider that an educational institution is able to create moral values independently of the sphere of material production, which allows education to influence changes in the social relations of society (Graham, 1985).

Representatives of the second scientific school T. Parson, R. Driven, A. Inkelye, M. Karnoi, S. Boulis, G. Levin argue that the most important characteristics of an educational institution are determined by their function in preparing young people for work (Carnoy \& Levin, 1985).

Both points of view are reduced to understanding the relationship of the educational institution and the labour market. The same position is held by Russian scientists. Thus, the Russian scientist A. Glazunov emphasizes 
that educational institutions form the labour market, which in turn forms and educates educational institutions, forcing them to look for pedagogical technologies and management models (Glazunov, 2004).

According to the American professor of economics and education T. Bailey, there is a gradual erasure of the boundaries between educational institutions and private companies, which is manifested in the integration of general and vocational education (The Changing U.S. Labor Market, 1994). Strengthening the interaction of developing firms and effective educational institutions has led American researchers to identify elements of a new paradigm of an effective school, implying the collective responsibility of students for academic achievement and professional training. Knowledge acquired through general education contributes to success in the implementation of work.

\section{THE PURPOSE OF THIS STUDY}

Is to try to identify the factors that both contribute to and hinder the development of the educational process.

\section{A hypothesis}

Of a possible strengthening of the relationship between educational training and vocational training is put forward. In American schools, forms of specialized vocational training are expanded. The educational program focuses on disciplines that help school graduates to adapt more quickly to the demands of the labour market.

\section{Study}

In the absence of a unified state education system, the structure of education in the United States is determined by each individual state. In accordance with the state laws adopted in each state, the duration of the school year, the schedule of studies, measures for the protection of students' health, and the requirements for obtaining diplomas for graduation are set. In most US states, the school policy is determined by the board of education and implemented by the department of education.

Education in the country has a multistage character. The educational system of the United States consists, firstly, of pre-school institutions for the education of children aged 3 to 5 years. Pre-school education is represented by both public and private institutions. Most kindergartens have a certain bias. In some preschool institutions, more attention is paid to artistic creativity, music education, in others - to mathematical knowledge. In state educational centres, tuition is free; in private schools it can reach $\$ 30,000$ per year. Federal and local governments provide about $90 \%$ of the funding of primary and secondary education and about $40 \%$ of the funding of higher education institutions.

The basis of the methodological activity of preschool institutions is the game principle, on the basis of which a smooth transition to reading, writing, drawing, singing, music, and physical education is carried out.

For American children, education begins at the age of five. The first year of study is called "kindergarten". At this stage of education, the creation of schools for small pupils takes place.

In some states, upon completion of the preschool institution, certificates are issued that state the pupil's achievements. The certificate is considered as a necessary document for enrolment in primary school.

The second level of education is an elementary school (primary school). American children enter primary school at the age of six. Primary school consists of six years of study. In the United States there are about 
90000 state and about 30000 private schools, in which about 55 million students study and more than 3 million teachers work. The average salary of a teacher in a public school exceeds 40 thousand dollars a year. The average annual expenditure per student is $\$ 6500$.

American elementary schools are characterized by a differentiated principle of class acquisition. Students are enrolled in "gifted", "normal", "incapable" groups, based on the results of a test that tests the child's mental abilities. Teaching in a group for "gifted" children implies a high level of requirements for pupils' knowledge and guides them to receive a serious education from the first days of classes. This approach has been criticized by many American scientists and educators. According to J. Braddock, such system does not allow for obtaining a full education of a significant part of American schoolchildren. In a number of states, students' mental abilities tests are cancelled (Fashey, 2000).

The content of the educational process is determined by the curriculum developed within the state. According to the curriculum, pupils tend to study such subjects as reading, writing, mother tongue, literature, arithmetic, geography, history, natural science, music, labour and physical education, and drawing. At the same time, arithmetic, drawing, musical and labour education get the same number of study hours.

The third level of education is secondary school which lasts from 7th to 12th grade. In this case, the 9-12th grades represent the highest secondary school (high school). The main subjects of the curriculum at the upper secondary level are English, mathematics, natural and social sciences. At the stage of high school, favourable conditions are created for the integration of general and vocational education of students. Close cooperation of schools and private business are established. Schools are provided with technological information; companies' experts are invited to teach. For the general preparation of students for the labour market, most educational schools offer courses in business, accounting, stenography, and work with office equipment. Acquired professional skills contribute to the development of civic responsibility among students and at the same time their thinking abilities.

In general education schools there are academic, professional, dual and general curriculums. Academic curriculum orients students to further education at the highest level. It is about studying at colleges and universities. A prerequisite for admission is a test that determines the student's talent factor of 90 and above. Students occupying an occupational curriculum are trained to start working after graduation. On the dual curriculum, students simultaneously master the programs of academic and professional profiles. On the general curriculum, more than half of the students study, who are undecided what profession they should choose (Stone \& Aliaga, 1997-1999).To study a number of subjects, students of different profiles can be combined into one group. For example, in classes in mathematics there are often students of different profiles at the same time. The academic profile is mainly for children from middle-income and high-income families (Stone, 20002).

Programs in general education subjects are compiled on the basis of profile differentiation. Programs in mathematics, English, and natural sciences are presented, depending on the students' knowledge and life goals, in three levels. Level one is for college-oriented students. The second and third levels suggest a less in-depth study of the subject. At the same time, the third level is intended for students with extremely weak knowledge.

Since secondary education is compulsory in the United States, children from low-income families have the opportunity to attend so-called public schools, where tuition is free. Most public schools teach predominantly children of members of national minorities. Many of these schools can give students only a general education. 
The qualifications of the teachers in these schools are not high enough. The same situation is characteristic of rural public schools, in which one third of all students in the country study. Thus, a significant portion of students do not receive enough knowledge necessary for the proper employment of young people. Work to identify the professional interests and aptitudes of students and to provide information about existing professions is not conducted at the proper level. Insufficiently trained students face difficulties after graduation. The salary of college graduates is about $20 \%$ higher than the salary of high school graduates.

In private schools, tuition fees are high. Among private schools, there are elite schools that prepare graduates of their schools for admission to the best universities in the country. Most private schools have been given the status of boarding houses, which means that students live in them throughout the school year. A certain percentage of children receive education at home by the decision of the parents according to a pre-approved program of study.

The educational process in the United States continues during the holidays through the organization of children's camps. In such camps, many children from different countries relax and improve their knowledge of the English language. English language training in the camp provides for a compulsory curriculum, which provides 20 hours of classes per week. Role-playing games are used in the process of learning.

There is no unified nationwide rating system in the United States. Some schools use a grading scale in numbers, others in letters. The five-grade alphabetic scale with the highest marks A (excellent), B (good), C (medium), D (lower than average), $F$ (unsatisfactory) was most widely used in schools in the country. The main form of verification of students' knowledge is testing.

After 12 years of study, graduates receive a high school diploma. Obtaining this diploma is a prerequisite for admission to colleges and universities. For foreign citizens to enter universities or colleges, they must have a similar education.

The United States is considered to be a country where technical teaching aids are actively used in secondary schools, and innovative training programs are being introduced. The actual task of the modernization of education is to teach students the basics of computer science and computer literacy, programming. Computer literacy is an integrator of general and vocational education. The fundamentals of programming are studied by students who are focused on further study or practical activities related to the computer.

The active use of telecommunications makes it possible to educate children both at school and at home. However, it should be noted that virtual schools could not demonstrate their advantage in comparison with traditional general education institutions.

After graduating from high school, students go to undergraduate school, which give them basic education. This is either a two-year community college, which form the basis of the vocational education system, after which students receive Associate Degree. Conventionally, this level of education can be called a "professional diploma". Or a four-year university education, which leads to the award of a bachelor's degree. An undergraduate degree can be obtained after obtaining an Associate Degree. The number of higher educational institutions in the United States exceeds 4,000. About 2 million teachers teach more than 15 million students in these universities. There are more private schools than state ones. A system of scholarships is widely developed, which represent both full funding and a certain percentage of the total cost of tuition and student loans that must be paid by the student within 10 years after graduation. Currently, the main focus is on training in natural and engineering specialties (STEM, 2016). 
After receiving a bachelor's degree, students have the opportunity to continue their education and get a master's degree. Typically, training in the magistracy lasts 2 years. This is a highly specialized training in the field in which a bachelor's degree was received. In the course of training in the magistracy, the student must prepare a serious scientific research in the specialty and uphold it. After receiving the master's degree, you can continue your studies to the degree of $\mathrm{PhD}$. This formation lasts 3-6 years on average.

Despite the predominance of private sources of funding in the field of higher education, significant development was received by state financial assistance in obtaining it. The main form of federal financial assistance for students on bachelor's programs is grants (The Condition of Education, 2016). The most common among government grants is the Pell Grant, which is a grant aid based on the student's financial situation and the income of his family. In order to qualify for a Pell Grant, you must be a US citizen or have documents confirming your stay in the country legally, namely, being a bachelor's student (Yemelyanov \& Chudinova, 2015). Unlike grants, each student can receive a federal loan.

In addition to federal aid, there are also grants provided by state and local governments. Financial support in obtaining education is also provided through the issuance of scholarships to students regardless of their financial situation, and assistance in obtaining temporary work for materially needy students.

One of the priorities of Barack Obama's social policy was to improve the education system in order to improve the results of student training. The task was to ensure that all students have the opportunity to finish high school, improve their academic performance, which would allow them to go to colleges or higher educational institutions.

Under the American Recovery and Reinvestment Act of 2009, four main areas of educational reform were identified. First of all, it is about the adoption of fairly stringent standards and criteria for assessing the quality of education. Secondly, the creation of a database and its use to improve the education system. Thirdly, on improving the efficiency of teachers. Fourthly, on improving the work of schools with the lowest results (American Recovery and Reinvestment Act of, 2009).

The Law provided for an increase in funding for education through grants to improve the work of schools, to support special education. Funds for the development of the education system were allocated through state stabilization funds, through federal programs. As a result of the use of funds from tax stabilization funds, education from preschool to senior school age in California, Indiana, Florida, etc. was financed. According to the federal "race to the top" grant program, money was transferred to states to increase student achievement and overcome the "gap" in progress, to improve the professional and pedagogical training of teachers, to improve the performance of schools with lower rates.

A special place in the educational strategy of $B$. Obama belonged to the role of universities in the formation of the national innovation system. Universities stimulate innovative and entrepreneurial activities of students by investing in standard programs and programs beyond the curriculum, which, for example, include practical tasks for developing business plans and creating clubs for entrepreneurship.

The basis of $\mathrm{D}$. Trump's public education program is based on the principle that students have the maximum choice of educational institutions of various types, including private, public or even religious. During the election campaign, D. Trump promised to allocate 20 billion dollars from the federal budget and spend them on grants so that students from low-income families could choose a good school, including a private one, so that parents, regardless of their income level, could provide a quality education to the child, based on his 
interests. At the same time, D. Trump offered to actively promote the system of vouchers and charter schools, whose graduates demonstrate better performance than their peers from general education schools. D. Trump also called for a change in the structure of teachers' salaries. D. Trump offered to pay premium allowances to teachers for work efficiency (Trump promises education reform).

D. Trump advocated the abolition of the federal educational standard. The Common Core standard is characterized by clear learning outcomes for each subject category at each stage of education, as well as formalized testing. In the US, this standard is criticized for the fact that it presupposes one thing, but it tests something completely different (Take and cancel).

Meanwhile, over the past two years of the presidency, D.Trump did not manage to fulfil his promises to reform the education system. The government was not able to redirect government education spending so that parents can choose to send their children to state, private, independent, specialized, religious schools or provide them with home schooling. Also, the system of uniform educational standards has not been cancelled yet (Year of the President).

At the same time, the process of closing public schools began in the US under D. Tramp, while encouraging the opening of new private schools. The motivation for this is the opinion of the leadership of the Ministry of Education of the country on higher quality education in private schools (How life has changed for ordinary Americans with the arrival of Trump). Increasingly, the leadership of the United States is in favour of the abolition of government credit programs for the development of education (Jenaabadi \& Khosropour, 2014).

\section{CONCLUSION}

Education in the USA is an important factor determining the success of an employee in the labour market. The basis of the educational process is the integration of general educational and vocational training of students. The level of education and professional training are the most important indicators of labour potential.

Today, in order to get a stable job, general educational training, professional knowledge and practical skills that students acquire in public, private, religious schools, as well as home-schooling are required.

State and local governments, as a rule, for the most part provide funding for primary and secondary education. Higher education is financed both by public and private funding.

The level of general sport education and vocational training is manifested when students enrol in colleges and at work. In the case of insufficient training of students, neither colleges nor companies will be able to noticeably improve the quality of the general education of young people. Meanwhile, the most important today for employment is the ability to work effectively with resources, technological equipment, modern technologies.

Particular attention to raising the level of education in the United States was given by the Obama administration. One of the main tasks set by Barack Obama was to enable Americans to realize their personal potential through increasing the accessibility of education for all citizens (State of the Union Address, 2015).

The task of increasing the efficiency of education has been set by President $\mathrm{D}$. Trump, although today most of $D$. Trump's promises to raise the level of education have not been fulfilled. 


\section{REFERENCES}

Educational Attainment in the US. census bureau. (2016).

Graham, P.A.(1985). Breaking the Silence about Educational Purpose IP.A. Graham // The Educational Digest. V. LI, №.1. - P.6-8.

Carnoy, M .; Levin, H.M. (1985). Democratic State / M. Carnoy, H.M. Levin. - Stanford (CA): Stanford Univ. Press, $307 \mathrm{p}$.

Glazunov, A.T. (2004). Management of vocational schools in the educational market / A.T. Glazunov - M $\therefore$ Publishing Center NOU ISOM, p. 41.

The Changing U.S. Labor Market. (1994). / Ed. by Eli Ginzberg. - Boulder (Col.): West view Press., Inc, P.154.

Fashey, J.A. (2000). Who Wants to Differentiate Instruction? We did ... /J.A. Fashey // Educational Leadership. C 70 - 72.

Stone J.R. III, Aliaga O.A. (1997-1999).Career and Technical Education, CareerPathways, and WorkBased Learning: Changes in Participation IJ.R. Stone III, O.A. Aliaga. - Columbus (OH): Nat. Research Center for Career and Techn. Education, 2003. - 53 p. https://doi.org/10.5328/cter30.2.125 Stone, J.R. lii. (2002). What do we know about career and technical education. Preliminary Findings from 2000 and 2001. NRCCTE Projects. Briefing Paper /J.R. Stone III. - St. Paul (MN): Nat. Research Center for Career and Technical Education, $19 \mathrm{p}$.

Science, Technology, Engineering and Mathematics (STEM) Education: A Primer. CRS, Wash. (2016). The Condition of Education 2016. URL: https://nces.ed.gov/pubs2016/2016144.pdf

Yemelyanov, U.V., Chudinova, K.O. (2015).State programs in education during the presidency of B.Obama // Russia and America in the XXI century. 2015.№1.S.6.

American Recovery and Reinvestment Act of (2009). Using the ARRA Funds to Drive School Reform and Improvement. URL: http://www.ed.gov

Trump promises education reform. URL: http://www.gazettco.com/tramp-obeshhaet-reformu-sistemyobrazovaniyal

Take and cancel: what Trump will do with the education of the United States. URL: https://newtonew.com/culture/trump-cancel-everything

Year of the President: what Trump did and for what he did not have time. URL: http://www.forumdaily.com/god-prezidenta-chto-vypolnil-i-chto-ne-vypolnil-tramp/

How life has changed for ordinary Americans with the arrival of Trump. URL: https://sputnik.by/radio/20170803/1030103197/kak-izmenilas-zhizn-prostyh-amerikantsev-sprihodom-trampa.html

State of the Union Address. (2015). https://doi.org/10.4135/9781506333496.n4

Hossein, Jenaabadi , Abolfazl, Khosropour. (2014). An investigation on the amount of employing total quality management principles by school principals and its' correspondence with their affectivity, UCT Journal of Social Sciences and Humanities Research, Issue 1,pp.13-17.

\section{(9) $\odot \Theta \Theta$}

This work is licensed under a Attribution-NonCommercial-NoDerivatives 4.0 International (CC BY-NC-ND 4.0). 